\title{
Editorial
}

\section{Peter-Emil-Becker-Price 2013}

\author{
Barbara Plecko ${ }^{1}$ \\ ${ }^{1}$ Department of Neuropediatrics, University of Zurich, \\ Zurich, Switzerland
}

Neuropediatrics 2014;45:69.

Each year Thieme and the "Gesellschaft für Neuropädiatrie" (GNP) have the pleasure to award the Peter-Emil-Becker-Price to an outstanding child neurologist. In 2013, the board of our society had the honor to nominate Prof. Ingrid Scheffer, a well-known researcher in the field of genetics of childhood epilepsies. Prof. Ingrid Scheffer is working as a pediatric neurologist and professor at the Florey Institute of Neuroscience and Mental Health and The University of Melbourne, Australia. Having been trained as a child neurologist in Australia and London and having received her $\mathrm{PhD}$ in Melbourne, Australia, Prof. Ingrid Scheffer is a clinical researcher in the very best sense, stressing the permanent importance of clinical phenotyping and translation of research findings into our everyday practice. Prof. Ingrid Scheffer and her group have made major contributions to the field of childhood epilepsies, evolving from linkage analyses on large autosomal dominant family pedigrees to novel seminal techniques as applied whole exome sequencing in large cohorts of isolated cases of epileptic encephalopathy. The participants of the 39th conference of the GNP, held in Innsbruck, Austria, from April 25, 2013, to April 28, 2013, had the pleasure of hearing a brilliant lecture on the progress that has been achieved in this field over the past two decades.

Her visionary approach and systematic work have been acknowledged with numerous awards, among them the L'Oréal-UNESCO Awards for Women in Science of 2012. This award especially highlights the active role of Prof. Ingrid Scheffer in promoting and guiding young women for research and to enable the "double carrier" as being mother and scientist in one life.

This issue of Neuropediatrics contains the highlights of the Peter-Emil-Becker-Price lecture of 2013 and takes us through

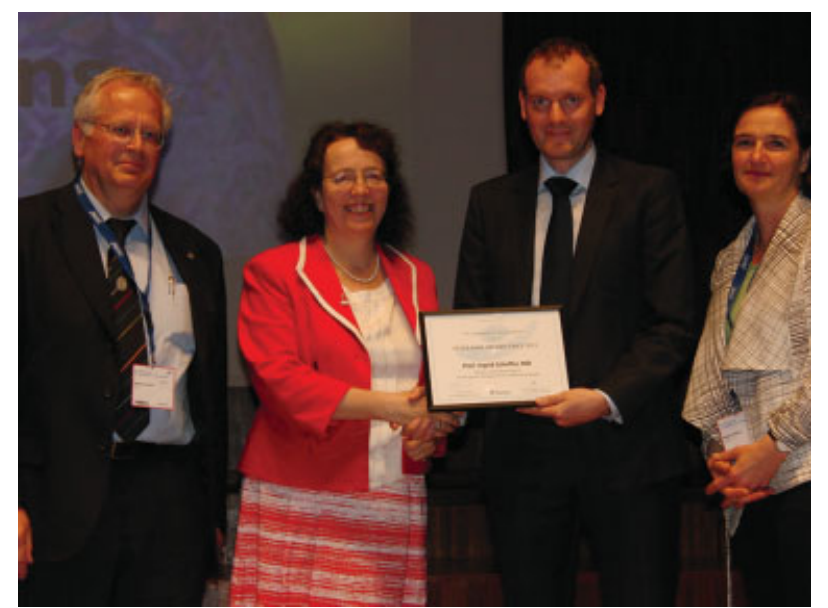

From left to right: Prof. Ulrich Stephani (Laudator), Prof. Ingrid Scheffer (Awardee), Graham Brumfield (Thieme Publishers), and Prof. Barbara Plecko (President of the GNP).

a 20-year fascinating journey of research on genetics in childhood epilepsies. ${ }^{1}$ We want to once more thank and congratulate Prof. Scheffer for her scientific achievements and will proudly add her name to the list of Peter-EmilBecker-Price awardees.

\section{Reference}

1 Scheffer IE. Epilepsy genetics revolutionizes clinical practice. Neuropediatrics 2014;45(2):70-74
Address for correspondence Prof. Dr. Barbara Plecko, MD, Current President of the

"Gesellschaft für Neuropädiatrie,"

University, Children's Hospital,

Steinwiesstrasse 75, CH-8032

Zurich, Switzerland

(e-mail: barbara.plecko@kispi.

uzh.ch). (c) 2014 Georg Thieme Verlag KG Stuttgart · New York
DOI http://dx.doi.org/ $10.1055 / \mathrm{s}-0034-1371548$. ISSN 0174-304X. 